\title{
MENSAGEM
}

\section{De Gramado a Brasília, retomando o crescimento da Medicina do Esporte}

\author{
Eduardo Henrique De Rose
}

O XIII Congresso Brasileiro de Medicina do Esporte, organizado pela Sociedade Gaúcha da especialidade, foi sem dúvida um grande sucesso. Este sucesso se baseou em alguns aspectos fundamentais, imprescindíveis para que qualquer evento deste tipo tenha êxito em sua execução.

O primeiro deles foi a participação de todos os profissionais que, de uma forma ou outra, se relacionam com a especialidade. Num enorme esforço, os gaúchos convidaram mais de cem expositores brasileiros, que atuaram em conferências, mesas-redondas, cursos e simpósios, abordando os mais diferentes aspectos de uma área em si mesmo multidisciplinar. Ademais, pela primeira vez, todos os ex-presidentes da Sociedade se fizeram presentes, participando ainda da Assembléia Geral, propiciando a experiência e o equilíbrio tão necessários para um crescimento e uma renovação que respeita o passado e as tradições.

Em segundo lugar, deve-se mencionar a excelente atmosfera de trabalho, alegre e descontraída em uma cidade pequena, e que propiciou e estimulou encontros paralelos, bem como a troca de experiências e de conhecimento entre os pesquisadores e profissionais de diversos Estados brasileiros.

Por último, a programação social e cultural do evento foi extraordinária, diferindo fundamentalmente do que costuma- va ser feito no passado neste tipo de Congresso, com conotação extremamente regionalista que priorizou a formação étnica do Estado, com uma marca muito forte no folclore, na gastronomia e na música gauchesca, que se fez presente até mesmo durante o evento, no Bolicho gaúcho montado junto aos expositores.

Agora, caberá aos organizadores do próximo congresso, a ser realizado em Brasília, capitalizar o sucesso e a experiência de Gramado e continuar projetando nossa Sociedade para uma integração maior com a área do Esporte e da Saúde, estabelecendo as nossas prioridades para o Terceiro Milênio, que tão rapidamente se aproxima.

A Sociedade Gaúcha de Medicina do Esporte, os Drs. João Ricardo Turra Magni e Félix Drummond, o excelente grupo de colegas que os apoiaram integrando a Comissão Coordenadora, estão todos de parabéns e podem considerar cumprida, e com um imenso sucesso, a difícil missão que receberam. Aos novos dirigentes da Sociedade Brasileira, como presidente da Federação Internacional, desejo uma gestão profícua e inteligente, que estabeleça definitivamente a nossa Especialidade no cenário médico nacional. 